\title{
Hubungan Kadar Transforming Growth Factor-Beta 1 (TGF- $\beta 1$ ) Urin dengan Proteinuria pada Anak Sindrom Nefrotik Resisten Steroid
}

\section{Relation between Urinary Transforming Growth Factor-Beta 1 (TGF-61) Levels and Proteinuria in the Children with Resistant Steroid Nephrotic Syndrome}

\author{
Prasetya Ismail $P^{1}$, L Enggar Fitri ${ }^{2}$, Krisni Subandijah ${ }^{3}$ \\ ${ }^{1}$ Laboratorium IImu Kesehatan Anak Rumah Sakit Umum Dr. Saiful Anwar Malang \\ ${ }^{2}$ Laboratorium Parasitologi Fakultas Kedokteran Universitas Brawijaya Malang \\ ${ }^{3}$ Laboratorium IImu Kesehatan Anak Rumah Sakit Umum Dr. Saiful Anwar Malang
}

\begin{abstract}
ABSTRAK
Transforming Growth Factor-Beta 1 (TGF-B1) menjadi perantara fibrosis interstisial, atrofi tubular, dan kerusakan gromelurus ginjal. Proteinuria menunjukkan prognosis yang buruk pada sindroma nefrotik. Terdapat kecenderungan persisten proteinuria pada sindroma nefrotik resisten steroid. Tujuan penelitian ini untuk membuktikan hubungan kadar Transforming Growth Factor-Beta 1 (TGF- $\beta 1$ ) urin dengan proteinuria pada anak sindrom nefrotik resisten steroid. Empat puluh lima sampel urin dikumpulkan terdiri dari 15 anak dengan sindrom nefrotik resisten steroid, 15 anak dengan sindrom nefrotik sensitif steroid dan 15 anak sehat. Sampel tersebut diukur kadar TGF- $\beta 1$ dan rasio protein-kreatinin kemudian dibandingkan. Terdapat perbedaan bermakna dalam pengukuran rasio protein-kreatinin $(p=0,000)$, tidak terdapat perbedaan bermakna dalam pengukuran TGF- $\beta 1$ dan tidak terdapat hubungan antara kadar TGF- $\beta 1$ dan rasio protein-kreatinine $(r=-0,222 ; p=0,427)$.
\end{abstract}

Kata Kunci: Kadar TGF- $\beta 1$ urin, proteinuria, rasio protein-kreatinin, sindrom nefrotik resisten steroid

\begin{abstract}
Transforming Growth Factor-Beta 1 (TGF-B1) mediates interstitial fibrosis, tubular atrophy and glomerular injury of the kidney. Proteinuria determine poor prognosis in nephrotic syndrome. There is evidence of persistent proteinuria in nephrotic syndrome resistant steroid. This study to determine wheter urinary Transforming Growth Factor-Beta 1 (TGF-B1) levels correlated to proteinuria in children with Resistant Steroid Nephrotic Syndrome. Forty five urine sample collected from thirthy nephrotic syndrome children which diagnosed resistant and sensitive steroid of each fifteen admitted in Department of Pediatric, Dr. Saiful Anwar hospital and fifteen healthy children are included in this study. Urine samples are analyzed for urinary TGF-61 levels and protein-creatinine ratio. These urinary TGF-61 levels and protein-creatinine ratio are compared and correlation is calculated. There is significant difference between group of resistant steroid nephrotic syndrome, sensitive steroid nephrotic syndrome and healthy children urine protein-creatinin ratio $(p=0,000)$, but there is no significant difference between groups for urinary TGF-61 levels $(p=0,051)$, and no correlation of resistant steroid nephrotic syndrome group between urinary TGF- 61 levels and protein-creatinine ratio $(r=-0,222 ; p=0,427)$.
\end{abstract}

Keywords: Proteinuria, protein-creatinine ratio, resistant steroid nephrotic syndrome, urinary TGF-61 levels

Jurnal Kedokteran Brawijaya, Vol. 27, No. 2, Agustus 2012; Korespondensi: Prasetya Ismail. Laboratorium IImu Kesehatan Anak Rumah Sakit Umum Dr. Saiful Anwar Malang, Jl. Jaksa Agung Suprapto No. 2 Malang Tel. (0341)343343Email: gastroduodenalis@yahoo.com 


\section{PENDAHULUAN}

Sindrom Nefrotik (SN) merupakan salah satu penyakit ginjal kronik yang sering pada anak dan juga merupakan kasus rujukan tersering pada dokter ahli ginjal anak. Di Negara berkembang angka kejadian SN tinggi. Di Indonesia dilaporkan 6 kasus tiap 100.000 anak per tahun (1). Data di laboratorium/SMF IImu Kesehatan Anak FK Unibraw-RSU. Dr. Saiful Anwar Malang antara bulan Januari 2002 hingga Desember 2006, menunjukkan sebanyak 101 (34\%) pasien SN dari 297 kasus seluruh penyakit ginjal (2).

Menurut The International Study of Kidney Disease in Children (ISKDC), pembagian berdasarkan respon klinis terhadap steroid dapat memprediksi prognosis yang lebih akurat dibandingkan dengan pembagian sesuai gambaran histopatologis pada anak dengan sindrom nefrotik idiopatik $(4,5)$. Sebagian besar penderita sindrom nefrotik idiopatik (SNI) dengan pengobatan standar steroid responnya baik, namun sebanyak $10-20 \%$ kasus SNI tidak respon terhadap pengobatan steroid Sindrom Nefrotik Resisten Steroid (SNRS). Disebut sebagai SNRS (menurut ISKDC) bila proteinuria masih tetap didapatkan setelah pemberian steroid dosis $60 \mathrm{mg} / \mathrm{m}^{2}$ atau $2 \mathrm{mg} / \mathrm{kg}$ berat badan, setiap hari selama 4 minggu (1). Sebanyak $50 \%$ kasus SNRS ini akan berkembang menjadi gagal ginjal terminal dalam waktu 1-4 tahun (6)

Telah dilaporkan adanya peran transforming growth factor- 8 (TGF- $\beta$ ) sebagai salah satu sitokin yang mengaktifkan patomekanisme biomolekuler yang mendasari progresifitas penyakit ginjal $(7,8)$. Hasil biopsi ginjal dari pasien dengan penyakit ginjal, menunjukkan hubungan antara ekspresi TGF- $\beta 1$ dengan luasnya fibrosis interstisiel, atrofi tubulus dan ekspresi aktin otot polos ginjal (9-11). Pada pasien dewasa dengan penyakit glomerulus yang mengalami proteinuria berat dan diterapi dengan prednison dan siklosporin A, ditemukan peningkatan ekspresi TGF- $\beta 1$ dalam jaringan ginjal (sitoplasma epitel tubulus proksimal, distal dan tubulus kolektivus) dan penurunan kadar TGF- $\beta 1$ urin pada kasus yang remisi pasca terapi, sedangkan kadar TGF- $\beta 1$ plasma tidak berubah bermakna (12). Kadar TGF- $\beta 1$ pada plasma tidak hanya mencerminkan produksinya di ginjal, namun juga mencerminkan TGF- $\beta 1$ yang dihasilkan oleh trombosit pasca degranulasi trombosit, sedangkan kadar TGF- $\beta 1$ urin hanya mencerminkan kelainan pada ginjal (12).

Pemeriksaan sampel urin pada anak dengan penyakit ginjal, rutin dilakukan termasuk pengukuran kadar protein urin (12). Proteinuria yang abnormal digolongkan menjadi: proteinuria glomerular, proteinuria tubular, proteinuria overload dan proteinuria karena perubahan hemodinamik. Keadaan proteinuria pada SNI termasuk jenis proteinuria glomerular (13). Pada keadaan proteinuria glomerulus ditemukan kadar TGF- $\beta 1$ urin yang tinggi $(10,11)$. Kadar TGF- $\beta 1$ yang tinggi dapat memicu terjadinya glomerulosklerosis yang ditandai dengan adanya proteinuria (14). Proteinuria merupakan salah satu faktor prognosis buruk pada penyakit glomerulus termasuk SN (15). Pada SNRS ditemukan proteinuria yang menetap (1). Pemeriksaan protein urin prosedurnya tidak invasif dan sampel mudah didapat dibandingkan dengan sampel darah (12) Penentuan proteinuria yang sering digunakan dan nilai diagnostiknya sama dengan pemeriksaan kuantitatif protein urin 24 jam yaitu rasio protein/kreatinin urin sewaktu (13).

Penelitian-penelitan tentang TGF- $\beta 1$ urin dihubungkan dengan proteinuria pada SN pada anak yang mengacu pada klasifikasi SN berdasarkan respon terhadap pengobatan steroid standar hingga saat ini sementara belum ada.

Penelitian ini membandingkan dan mencari hubungan antara kadar TGF- $\beta 1$ urin dan rasio protein/kreatinin urin pada pada anak dengan SNRS.

\section{METODE}

Penelitian ini merupakan penelitian deskriptif analitik dengan metode potong lintang untuk membandingkan kadar TGF- $\beta 1$ urin dan rasio protein/kreatinin urin pada anak dengan SNSS dan SNRS.

Subjek yang diambil sampel urin penelitian adalah anak dengan sindrom nefrotik idiopatik, berusia 1-14 tahun yang dirawat di Lab/SMF IImu Kesehatan Anak RSU dr. Saiful Anwar Malang dan bersedia ikut serta dalam penelitian dengan pernyataan tertulis dalam informed consent.

Pengambilan sampel dilakukan secara consecutive sampling. Anak yang menderita sindrom nefrotik sekunder dan sindrom nefrotik kongenital dieksklusi dari sampel sindrom nefrotik penelitian. Anak yang menderita kelainan bawaan atau penyakit ginjal lain atau terdapat penyakit/riwayat atopi serta riwayat/sedang dalam pengobatan steroid dieksklusi dari kriteria sampel kontrol sehat. Sampel penelitian dikelompokkan menjadi kelompok SNSS, SNRS dan kelompok kontrol. Kriteria anak yang dimasukkan dalam SNSS ataupun SNRS sesuai dengan Konsensus Tatalaksana Sindrom Nefrotik Idiopatik pada Anak tahun 2008 (5).

Sampel urin yang diambil untuk pengukuran kadar TGF- $\beta 1$ urin diambil sebanyak $5 \mathrm{ml}$ dari urin tampung 24 jam dan disimpan supernatant hasil sentrifus sampel pada suhu $-20^{\circ} \mathrm{C}$. Setelah semua sampel terkumpul kemudian dilakukan penentuan kadar TGF- $\beta 1$ dengan metode enzyme immunoassay menurut prosedur standar kit Human TGF-B1 Immunoassay (R\&D Systems, UK). Penentuan kadar TGF- $\beta 1$ urin ini dilakukan di Lab. Fisiologi FK-UNIBRAW Malang.

Sedangkan sampel urin yang dibutuhkan untuk menentukan rasio protein/kreatinin urin sebanyak $5 \mathrm{~mL}$ urin sewaktu yang diukur kadar masing-masing (protein dan kreatinin urin) secara langsung menggunakan Autoanalyzer Hitachi 902. Rasio protein/kreatinin urin sewaktu dihitung dengan membagi kadar protein urin sewaktu (dalam satuan $\mathrm{mg} / \mathrm{dL}$ ) dengan kadar kreatinin urin sewaktu (dalam satuan $\mathrm{mg} / \mathrm{dL}$ ). Pengukuran kadar protein dan kreatinin urin dilakukan di Lab. Pattimura Malang.

Alat dan bahan yang diperlukan dalam pengukuran kadar TGF- $\beta 1$ urin meliputi: mikrotiter plate, mikropipet 10-100 $\mu \mathrm{l}$ dan 200-1000 $\mu \mathrm{L}$, tabung sampel, tabung eppendorf, tabung sentrifus, blue and yellow tip, botol penyemprot, dispenser manifold atau automated microplate washer, tabung polypropilen, refrigerator, sentrifus, chamber, microplate ELISA reader dengan absorbansi panjang gelombang $450 \mathrm{~nm}$, kit standar Human TGF-B1 Immunoassay (R\&D Systems, UK) terdiri dari: TGF- $\beta 1$ microplate, TGF- $\beta 1$ konjugat, Assay Diluent RD1-21, 
Calibrator Diluent RD5-53 Concentrate, Wash Buffer Concentrate, stop solution (asam hidroklorida), dan Substrate Solution terdiri dari Reagen Warna A (Hidrogen peroksida) dan reagen warna $B$ (tetrametilbenzidin), serta bahan untuk mengaktifkan TGF- $\beta 1$ sampel urin yakni $\mathrm{HCl} 1$ $\mathrm{N}$ dan $\mathrm{NaOH}$ 1,2 N/HEPES 0,5 M. Hasil pengukuran kadar TGF- $\beta 1$ urin dinyatakan dalam $\mathrm{ng} / 24$ jam.

Data statistik karakteristik sampel penelitian disajikan dalam bentuk persentase. Komparasi perbandingan variabel tergantung diantara 3 kelompok (kontrol, SNSS dan SNRS) menggunakan uji statistik one way ANOVA disertai uji post hoc LSD untuk kelompok SNSS dan SNRS. Korelasi variabel tergantung pada kelompok SNRS menggunakan uji korelasi Pearson dengan nilai interval kepercayaan $95 \%$. Semua data dianalisa menggunakan Statistical Package for the Social Sciences (SPSS 17) for Windows. Hasil signifikan dinyatakan bila nilai $p<0,05$.

Komisi Etik Penelitian Kedokteran dan Kesehatan RSU Dr. Saiful Anwar Malang menyetujui penelitian ini. Setiap penderita dan keluarga yang terlibat dalam penelitian ini telah diberikan penjelasan dan menandatangani informed consent.

\section{HASIL}

Pada studi ini dengan consecutive sampling didapatkan 45 sampel, yang terbagi menjadi 3 kelompok yaitu kelompok sindrom nefrotik resisten steroid (SNRS), sindrom nefrotik sensi1tif steroid (SNSS) dan kontrol dengan masingmasing kelompok terdiri dari 15 subyek terkumpul.

Pada kelompok SNRS, terapi yang diberikan yaitu siklofosfamid oral pada 6 pasien, siklofosfamid pulse pada 8 pasien dan methylprednisolone pulse pada 1 pasien. Pemeriksaan biopsi dilakukan pada 2 pasien dengan SNRS dimana didapatkan hasil kelainan minimal (SNKM) dan glomerulosklerosis fokal segmental (GSFS).

Perbandingan kadar TGF- $\beta 1$ dan rasio protein/kreatinin urin antar kelompok penelitian (SNSS, SNRS dan kontrol) dan kelompok SN (SNSS dan SNRS) masing-masing dapat dilihat pada Tabel 1 dan 2.

Tabel 1. Perbandingan kadar TGF- $\beta 1$ dan rasio protein/kreatinin urin antara kelompok SNSS, SNRS dan kontrol

\begin{tabular}{lcccc}
\hline \multirow{2}{*}{ Variabel } & \multicolumn{3}{c}{ Rata rata \pm SD } & \multirow{2}{*}{ Nilai $\boldsymbol{p}^{*}$} \\
\cline { 2 - 4 } & SNRS & SNSS & Kontrol & \\
\hline $\begin{array}{l}\text { Kadar TGF- } \beta 1 \text { Urin } \\
\text { (ng/24 jam) }\end{array}$ & $0,131 \pm 0,01$ & $0,140 \pm 0,00$ & $0,138 \pm 0,00$ & 0,051 \\
$\begin{array}{l}\text { Rasio Protein- } \\
\text { Kreatinin Urin }\end{array}$ & $2,20 \pm 0,84$ & $3,28 \pm 1,16$ & $0,56 \pm 0,22$ & 0,000 \\
\hline
\end{tabular}

Dari hasil analisis uji statistik one way ANOVA tidak didapatkan perbedaan yang bermakna perbandingan kadar TGF- $\beta 1$ pada ketiga kelompok (SNSS, SNRS dan kontrol) dengan $p=0,051$. Kadar TGF- $\beta 1$ pada kelompok SNSS lebih tinggi (rerata 0,140 \pm SD 0,00), berikutnya kadar TGF- $\beta 1$ kelompok kontrol (rerata 0,138+SD 0,00) dan terendah pada kelompok SNRS (rerata 0,131+SD 0,01). Perbandingan rasio protein/kreatinin urin pada ketiga kelompok (SNSS, SNRS dan kontrol) dengan uji statistik yang sama, didapatkan perbedaan yang bermakna dengan nilai $p=0,000$ (signifikan jika nilai $p<0,05)$ (Tabel 1 ).

Rasio protein/kreatinin urin tertinggi pada kelompok SNSS (rerata 3,28 \pm SD 1,16), kemudian diikuti oleh rasio protein/

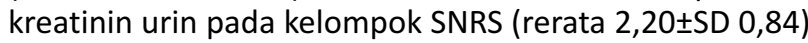
dan paling rendah pada kelompok kontrol (rerata $0,56 \pm S D$ 0,22).

Berdasarkan analisis statistik uji post hoc test $L S D$ kadar TGF- $\beta 1$ pada kelompok SNRS dibandingkan dengan kelompok SNSS didapatkan perbedaan bermakna dengan nilai $p=0,022$, sedangkan dibandingkan dengan kelompok kontrol tidak berbeda bermakna dengan nilai $p=0,059$.

Tabel 2. Kadar TGF- $\beta 1$ dan rasio protein/kreatinin urin pada SNRS dibandingkan dengan kelompok SNSS dan kontrol

\begin{tabular}{llllll}
\hline & \multirow{2}{*}{ Perbedaan Rerata } & \multicolumn{2}{c}{ IK 95\% } & \multirow{2}{*}{ Nilai p* } \\
\cline { 4 - 5 } & & & Minimum & Maksimum & \\
\hline SNRS & TGF- $\beta 1$ & $-0,007$ & & & 0,059 \\
vs & Rasio PK & 0,578 & $-0,015$ & 0,000 & 0,000 \\
Kontrol & & & 0,470 & 0,726 & \\
SNSS & TGF- $\beta 1$ & 0,001 & & & 0,667 \\
vs & Rasio PK & 0,776 & $-0,006$ & 0,009 & 0,000 \\
Kontrol & & & 0,648 & 0,904 & \\
SNRS & TGF- $\beta 1$ & $-0,009$ & & & 0,022 \\
vs & Rasio PK & $-0,177$ & $-0,169$ & $-0,001$ & 0,008 \\
SNSS & & & $-0,305$ & $-0,049$ & \\
\hline
\end{tabular}

Rasio protein/kreatinin urin pada kelompok SNRS dibandingkan dengan kelompok SNSS dan kelompok kontrol didapatkan perbedaan bermakna dengan nilai $p$ masing-masing 0,008 dan 0,000.

Hasil analisis statistik korelasi Pearson menunjukkan bahwa tidak ada hubungan yang bermakna antara peningkatan kadar TGF- $\beta 1$ urin dengan rasio protein/kreatinin urin pada kelompok SNRS $(p=0,22 ; p=$ $0,427)$ maupun SNSS $(r=-0,22 ; p=0,469)$.

\section{PEMBAHASAN}

Penelitian ini merupakan penelitian cross sectional untuk membuktikan adanya hubungan antara kadar TGF- $\beta 1$ urin dengan rasio protein/kreatinin urin pada pasien SNRS anak.

Karakteristik sampel pada penelitian didapatkan rentang umur 1-14 tahun dengan umur rata-rata 6 sampai 7 tahun, pada jenis kelamin didapatkan rasio laki-laki dibandingkan perempuan 4:1 pada SNRS dan 2:1 pada SNSS. Hal ini sesuai dengan insiden sindrom nefrotik, dimana pada 251 anak berumur 3-15 tahun dengan SN, ditemukan $85 \%$ sindrom nefrotik idiopatik sedangkan $15 \%$ SN sekunder (16). Dengan perbandingan insiden didominasi laki-laki dengan rasio $2: 1$, rasio ini pada anak laki-laki akan menurun seiring dengan bertambahnya usia menjadi remaja dan dewasa.

Penelitian ini dilakukan berdasarkan hipotesis bahwa resistensi terhadap glukokortikoid diperantarai oleh aktivasi faktor transkripsi dan produksi limfokin yang menginisiasi dan mempertahankan respon inflamasi yang diperantarai sebagian besar oleh sel $\mathrm{T}$ serta adanya 
diperantarai sebagian besar oleh sel T serta adanya gangguan pada sel T regulator pada penderita SNRS (18). Konsep aktivasi supresi kompetitif ini didukung oleh bukti klinis yaitu sebagian kasus resisten steroid dapat diatasi dengan pemberian terapi glukokortikoid intavena dengan dosis yang sangat besar. Terdapat beberapa mediator potensial resistensi sel T pada glukokortikoid, IL-2 dan IL-4 dikatakan dapat menginduksi resistensi terhadap glukokortikoid pada sel limfosit normal $(19,20)$ Diperkuat pula dengan penelitian Neuhaus et al (21) dalam penelitiannya yang menunjukkan adanya peningkatan IL2 , IL-4 dan IFN- $\gamma$ pada penderita SNSS relaps dibandingkan dengan SNSS remisi. Penelitian lain oleh Strehlau et al (22) menemukan bahwa kadar TGF- $\beta 1$ urin, sebagai salah satu sitokin penting yang berperan dalam terjadinya fibrosis ginjal, kadarnya meningkat pada kasus FSGS.

Pada penelitian ini, subjek penelitian telah menjalani terapi steroid selama 4 minggu. Steroid memiliki efek yang berbeda terhadap ekspresi sitokin pada SNSS dan SNRS. Sensitifitas individu terhadap pemberian kortikosteroid eksogen tergantung pada farmakokinetik dan farmakodinamik steroid itu sendiri, jumlah reseptor glukokortikoid dan afinitas pengikatan reseptor, efisiensi translokasi reseptor menuju nukleus dan ikatan DNA serta proses sekuensial yang terjadi pada nucleus (23). Beberapa kelainan genetik yang melibatkan barier filtrasi glomerulus diketahui sebagai penyebab resistensi steroid pada SN (24). Penelitian genetik terkini menemukan gen C epsilon sebagai gen yang mengalami mutasi pada beberapa individu dengan SN dan berespon terhadap steroid dan siklosporin (25).

Penggunaan sampel urin merupakan prosedur yang tidak invasif dan sampel mudah didapatkan dibandingkan sampel darah (26). Pada keadaan proteinuria glomerular pada SN ditemukan kadar TGF- $\beta 1$ urin yang tinggi $(10,11)$. Kadar TGF- $\beta 1$ yang tinggi dapat memicu terjadinya glomerulosklerosis yang ditandai dengan adanya proteinuria (14). Diketahui bahwa proteinuria berat dapat sebagai faktor risiko prognosis buruk pada kebanyakan penyakit glomerulus. Efek dari proteinuria tersebut akibat dari pelepasan bahan toksik dari lisosom yang diikuti oleh reabsorpsi protein terfiltrasi dalam jumlah besar oleh sel epitel tubulus dengan cara endositosis (12). Stimulasi dari sel epitel tubulus akan mencetuskan aktivasi gen transkripsi yang mengkode peptida vasoaktif dan kemotaktik seperti endothelin-1 (ET-1) dan monocyte chemoattractant protein-1 (MCP-1). Peningkatan pelepasan peptida tersebut akan meningkatkan akumulasi monosit pada jaringan interstisial ginjal dan menstimulasi fibroblast dan myofibroblas pada area yang sama sehingga mengakibatkan inflamasi interstisial dan fibrosis.

Tidak didapatkan perbedaan bermakna secara statistik kadar TGF- $\beta 1$ urin antara kelompok kontrol, kelompok SNSS dan SNRS, namun antara kelompok SNRS dan SNSS didapatkan perbedaan yang bermakna. Kadar TGF- $\beta 1$ urin menunjukkan peningkatan pada kelompok SNSS dan penurunan pada kelompok SNRS dibandingkan dengan kelompok kontrol. Peningkatan maupun penurunan rerata kadar TGF- $\beta 1$ urin tersebut dibandingkan dengan kelompok kontrol tidak berbeda bermakna dengan masing-masing nilai $p=0,059$ (SNRS) dan $p=0,667$ (SNSS). Woroniecki et al dalam penelitiannya yang membandingkan profil sitokin antara penderita SNSS dan SNRS menunjukkan hasil adanya peningkatan kadar TGF$\beta 1$ urin dengan metode ELISA pada SNSS dan SNRS, namun secara statistik tidak berbeda signifikan dengan $p=0,14$ (27). Temuan ini dimungkinkan karena beberapa sampel kelompok SNRS pada penelitian ini telah mendapatkan terapi Angiotensin Converting Enzyme (ACE) inhibitor yang diketahui mampu menurunkan kadar TGF- $\beta 1$ (28).

Pengukuran rasio protein/kreatinin pada penelitian ini dilakukan dengan pengambilan sampel urin secara sewaktu. Penelitian Hartanto et al (29) pada 40 penderita SN anak menyebutkan bahwa tidak ada perbedaan bermakna antara rasio protein/kreatinin urin dengan waktu pengambilan sampel urin (sampel urin pagi, siang dan malam hari) dengan korelasi yang sangat kuat pada ketiga kelompok (29). Penelitian tersebut mendukung bukti bahwa untuk mengukur kadar ekskresi protein urin (proteinuria) dapat digunakan sampel urin sewaktu yang sama akuratnya dibandingkan dengan sampel urin yang dikumpulkan selama 24 jam. Pada penelitian ini dibuktikan bahwa terdapat perbedaan bermakna rasio protein/kreatinin urin diantara kelompok kontrol, kelompok SNSS dan SNRS dengan $p=0,000$, diperkuat dengan perbandingan antara kelompok SNSS dan SNRS yang berbeda bermakna dengan $p=0,008$.

Didapatkan penurunan rasio protein/kreatinin urin pada kelompok SNRS dibandingkan dengan kelompok SNSS, namun kadar kreatinin urin pada kelompok SNRS lebih tinggi dibandingkan dengan pada kelompok SNSS. Kerusakan glomerulus maupun tubulus akibat proses glomerulosklerosis akan meningkatkan kadar kreatinin urin. Penggunaan obat ACE inhibitor diketahui mampu menurunkan laju filtrasi glomerulus (5), pada penelitian ini beberapa anak kelompok SNRS menggunakan obat tersebut sehingga memungkinkan terjadinya penurunan rasio protein/kreatinin urin.

Pada penelitian ini tidak didapatkan adanya korelasi signifikan antara kadar TGF- $\beta 1$ urin dengan rasio protein/kreatinin urin pada kelompok SNRS. Hal ini menunjukkan adanya faktor-faktor lain yang mempengaruhi peningkatan kadar TGF- $\beta 1$ urin dan rasio protein/kreatinin urin serta resistensi steroid baik pada tingkat gen, DNA (transkripsi dan translasi), transduksi sinyal molekuler yang melibatkan sitokin-sitokin proinflamasi dan anti inflamasi. Woroniecki et al dalam penelitiannya menduga bahwa peningkatan eksresi TGF$\beta 1$ urin pada awal perjalanan SN lebih berkaitan dengan histopatologi SN dibandingkan dengan proteinuria (27). $\mathrm{Hal}$ ini sesuai dengan hasil penelitian Strehlau et al. yang menyatakan ditemukannya ekspresi gen TGF- $\beta 1$ yang meningkat pada 23 dari 29 anak SNRS dan 18 dari 20 anak dengan FSGS (21).

Penelitian ini dibatasi oleh tidak diukurnya kadar TGF- $\beta 1$ serum maupun jaringan ginjal, meskipun beberapa peneliti yang lain menunjukkan adanya hubungan antara kadar TGF- $\beta 1$ serum dan urin diantara penderita SN, baik yang sensitif maupun resisten steroid. Kekurangan penelitian yang lain adalah parameter yang digunakan untuk melihat responsifitas steroid pada anak dengan SN hanya satu parameter saja. Diketahui bahwa TGF- $\beta$ dari beberapa literatur masih kontroversial dalam hal mekanisme kerjanya, terutama yang dikaitkan dengan 
dengan kerja glukokortikoid. Karena merupakan mediator yang pleiotropik sama halnya dengan glukokortikoid, keduanya dapat saling memperantarai efeknya satu sama

\section{DAFTAR KEPUSTAKAAN}

1. Roth KS, Amaker BH, and Chan JCM. Nephrotic Sydrome: Pathogenesis and Management. Pediatrics in Review. 2002; 23(7): 237-247.

2. Krisni S. Pola Penyakit Ginjal pada Anak di RS Saiful Anwar Malang Tahun 2002-2006. Pertemuan Ilmiah Tahunan Ilmu Kesehatan Anak Ikatan Dokter Anak Indonesia (PITIKA-IDAI). Yogyakarta, 2007.

3. ISKDC. Nephrotic Syndrome in Children: Prediction of Histopathology from Clinical and Laboratory Characteristics at Time of Diagnosis. Kidney International. 1978; 13(2): 159-165.

4. Gulati S, Sengupta D, Sharma RK, et al. Steroid Resistant Nephrotic Syndrome: Role of Histopathology. Indian Pediatrics. 2006; 43(1): 55-60.

5. Alatas H, Tambunan T, Trihono PP, and Pardede SO. Konsensus Tatalaksana Sindrom Nefrotik Idiopatik pada Anak. Jakarta: UKK Nefrologi IDAI; 2005.

6. Bagga A and Mantan M. Nephrotic Syndrome in Children. Indian Journal of Medical Research. 2005; 122: 13-28.

7. Border WA and Noble NA. Transforming Growth Factor $\beta$ in Tissue Fibrosis. The New England of Medical Journal. 1994; 331: 1286-1292.

8. Border WA, Okuda S, Nakamura T, Languino LR, and Ruoslahti E. Role of TGF- $\beta 1$ in Experimental Glomerulonephritis. Ciba Foundation Symphosium. 1991; 157: 178-189.

9. Schiffer M, Bitzer M, Roberts IS, et al. Apoptosis in Podocytes Induced by TGF-beta and Smad7. The Journal of Clinical Investigation. 2001; 108(6): 807-816.

10. Bottinger EP and Bitzer M. TGF- $\beta$ Signaling in Renal Disease. Journal of American Society of Nephrology. 2002; 139(10): 2600-2610.

11. Cheng J and Grande JP. Transforming Growth Factor- $\beta$ Signal Transduction and Progressive Renal Disease. Experimental Biology and Medicine. 2002; 227(11): 943-956.

12. Goumenos DS, Tsakas S, El Nahas AM, et al. Transforming Growth Factor- $\beta 1$ in The Kidney and Urine of Patients with Glomerular Disease and Proteinuria. Nephron Clinical Practice. 2009; 111(2): 127-132.

13. Alatas H, Tambunan T, Trihono PP, and Pardede SO. Buku Ajar Nefrologi Anak. Jakarta: IDAI; 2002.

14. Ma L and Fogo AB. Role of Angiotensin II in Glomerular Injury. Seminars in Nephrology. 2001; 21(6): 544-553.

15. Jerums G, Panagiotopoulos S, Tsalamandris C, Allen TJ, Gilbert RE, and Comper WD. Why is Proteinuria Such an Important Risk Factor for Progression in Clinical Trials? Kidney International Supplement. 1997; 63: S87-S92. lain baik di tingkat transkripsi, pasca transkripsi maupun di tingkat DNA site Glucocorticoid Responsive Element (GRE).

16. Habashy D, Hodson E, and Craig J. Interventions for Idiopathic Steroid-Resistant Nephrotic Syndrome in Children. Cochrane Database of Systematic Review. 2006; 19(CD003594).

17. Eddy AA and Symons JM. Nephrotic Syndrome in Childhood. The Lancet. 2003; 362(9384): 629-639.

18. Aviles VM, Manning J, Ochoe AC, and Zea AH. Decreased Expression of T-cell NF-KB p65 Subunit in Steroid-Resistant Nephrotic Syndrome. Kidney International. 2004; 66(1): 6-7.

19. Neuhaus TJ, Shah V, and Callard RE. T-lymphocyte Activation in Steroid-Sensitive Nephrotic Syndrome in childhood. Nephrology Dialysis Transplantation. 1995; 10(8): 1348-1352.

20. Corebima BIRV, Subandiyah K, dan Fitri LE. Ekspresi dan Aktivasi Sub Unit p65 NF-KB pada Sel Mononuklear Penderita Sindrom Nefrotik Resisten Steroid Anak. Jurnal Kedokteran Brawijaya. 2009; 25(3): 133-137.

21. Neuhaus TJ, Wadhwa M, Callard R, and Barrat TM. Increased IL-2, IL-4 and Interferon- (IFN- in SteroidSensitive Nephrotic Syndrome. Clinical and Experimental Immunology. 1995; 100(3):475-479.

22. Strehlau J, Schachter AD, Pavlakis M, Singh A, Tejani A, and Strom TB. Activated Intrarenal Transcription of CTL-effectors and TGF-B1 in Children with Focal Segmental Glomerulosclerosis. Kidney International. 2002; 61: 90-95.

23. Bamberger CM, Schulte HM, and Chrousos GP. Molecular Determinants of Glucocorticoid Receptor Function and Tissue Sensitivity to Glucocorticoids. Endocrine Reviews. 1996; 17(3): 245-261.

24. Tryggvason K, Patrakka J, and Wartiovaara J. Hereditary Proteinuria Syndromes and Mechanisms of Proteinuria. The New England Journal of Medicine. 2006; 354: 1387-1401.

25. Hinkes B, Wiggins RC, Gbadegesin R, et al. Positional Cloning Uncovers Mutations in PLCE1 Responsible for a Nephrotic Syndrome Variant that May be Reversible. Nature Genetics. 2006; 38(12): 1397-1405.

26. Tsakas S and Goumenos DS. Accurate Measurement and Clinical Significance of Urinary Transforming Growth Factor-Beta1. American Journal of Nephrology. 2006; 26(2): 186-193.

27. Woroniecki RP, Shatat IF, Supe K, Du Z, and Kaskel FJ. Urinary Cytokines and Steroid Responsiveness in Idiopathic Nephrotic Syndrome of Childhood. American Journal of Nephrology. 2008; 28(1): 83-90.

28. Scaglione R, Argano C, Corrao S, Di Chiara T, Licata A, and Licata G. Transforming Growth Factor B-1 and Additional Renoprotective Effect of Combination ACE Inhibitor and Angiotensin II Receptor Blocker in Hypertensive Subjects with Minor Renal 
Abnormalities: A 24-Week Randomized Controlled Trial. Journal of Hypertension. 2005; 23(3): 657-664.

29. Hartanto J, Juffrie $M$, dan Ardani P. Perbandingan
Rasio Protein Kreatinin Urin Sesaat pada Pagi, Siang dan Malam Hari pada Anak dengan Sindrom Nefrotik. Berkala Kesehatan Klinis. 2009; 15(1): 37-41. 